\title{
COMPARATIVE REVIEW OF REGULATORY FRAMEWORK OF VIRTUAL CURRENCY (CRYPTOCURRENCY) IN SELECTED COUNTRIES
}

\author{
Marcin Kasprzyk
}

\begin{abstract}
In the era of rapid technological progress, the legislators of individual countries face the challenge of submitting new technological phenomena to the legal framework. The business operation in the field of virtual currencies (cryptocurrencies), widely, in the financial technology sector (hereinafter referred to in as "fintech"), create a chance to attract investors and develop the economy. On the other hand, the same might be misused for illegal purposes, such as, in particular, money laundering or financing of terrorism. This study provides for an overview of the legal regulations of selected states in the field of virtual currencies (cryptocurrencies). Although, presented laws and regulations herein are in favour of the cryptocurrencies, the scope of implemented acts varies significantly.
\end{abstract}

Key words: virtual currency (cryptocurrency), distributed ledger technology, regulatory framework.

\section{INTRODUCTION}

Prior to presentation of selected laws and regulations, please find these introductory notes of a terminological nature for the convenience of the reader as well as to disambiguate terms used herein.

The basic definition of term "cryptocurrency" was proposed by M. Szymankiewicz. According to this author a cryptocurrency is a virtual currency

* Ph.D candidate, I Department of Civil Law, Faculty of Law, Canon Law, and Administration at the John Paul II Catholic University of Lublin. 
based on cryptography ${ }^{1}$. According to K. Piech both the cryptocurrency and the virtual currency fall into the conceptual range of the overreaching term "digital money" or "digital currency", that is a mean of exchange other than in physical form ${ }^{2}$. The foregoing author distinguishes the cryptocurrency and the virtual currency based on the scope of use thereof as according to him use of the cryptocurrency is unlimited whereas use of the virtual currency is limited to particular purposes such as social networks or games ${ }^{3}$.

The cryptocurrency itself may be also divided into coins and tokens. To simplify, a coin is a cryptocurrency embedded on its own developed distributed ledger technology $y^{4}$, whereas a token is a cryptocurrency without its own distributed ledger technology 5 .

Without prejudice to the quoted definitions, the virtual currency (cryptocurrency) is based on decentralized peer-to-peer network, that is a type of network architecture in which each node is equal and connected directly to others nodes. The foregoing differentiates the same from client-server architecture where nodes are divided into those that provide resources (servers) and those that use such resources (clients).

In addition, please note that the term "currency" with regard to the virtual currency (cryptocurrency) is used conventionally as the virtual currency (cryptocurrency) is not a legal tender .

Both terms will be used interchangeably hereinafter unless the context provides otherwise.

Marcin Szymankiewicz, 2014, Bitcoin wirtualna waluta internetu, Gliwice, Onepress, 102 .

2 Krzysztof Piech, Leksykon pojęć na temat technologii blockchain i kryptowalut. Strumień „Blockchain i Kryptowaluty” programu „Od papierowej do cyfrowej Polski”, December 20, 2018. https://www.gov.pl/documents/31305/0/leksykon_pojec_na_temat_ technologii_blockchain_i_kryptowalut.pdf/77392774-1180-79ab-4dd5-089ffab37602.

Krzysztof Piech, op. cit.

4 Although the term "blockchain" is more popular, it is narrower. Please see note above.

5 Please see: Dariusz Szostek, Blockchain a prawo, Warszawa, C.H. Beck, 2018, 129 and https://kryptomagazyn.pl/podzial-kryptowalut-czym-roznia-sie-coiny-tokeny/, November 18, 2018.

6 Marcin Szymankiewicz, op. cit.

7 Konrad Zacharzewski, „Bitcoin jako przedmiot stosunków prawa prywatnego”, MoP 21(2014): 1136. 
The concept of cryptocurrency is connected with the concept of aforementioned distributed ledger technology. It is a consensus of replicated, shared, and synchronized digital data geographically spread across multiple sites, countries, or institutions ${ }^{8}$. The distributed ledger technology is better known for the name "blockchain", which however is narrower?

It is interestingly enough, that according to available data there are already 2073 cryptocurrencies ${ }^{10}$. The dominant position of bitcoin among cryptocurrencies remains unchanged ${ }^{11}$ and that state will probably continue as the capitalization of bitcoin amounts to $\$ 65,873,534,441$, whereas the capitalization of the second cryptocurrency - Ripple amounts to $14,550,598,802$ as of the end of $2018^{12}$.

In the margin, it is a pity that the postulate of domesticating of the cryptocurrency in Poland formulated in relation to bitcoin in pioneering study by K. Zacharzewski, despite the passage of years, still has not been implemented $^{13}$.

\section{REGULATION OF CRYPTOCURRENCY IN MALTA}

Malta has been named with slight exaggeration by Mr. Silvio Schembri who holds the capacity of the Junior Minister for Financial Services, Digital Economy \& Innovation within the Office of the Prime Minister of Malta as the "Blockchain Island" on several occassions ${ }^{14}$. However, the

8 https://assets.publishing.service.gov.uk/government/uploads/system/uploads/attachment_data/file/492972/gs-16-1-distributed-ledger-technology.pdf, November 26, 2018.

9 Krzysztof Piech, op. cit.; Dariusz Szostek, Blockchain a prawo..., 27-50.

10 https://coinmarketcap.com/, December 12, 2018.

11 Grzegorz Sobiecki, "Regulowanie kryptowalut w Polsce i na świecie na przykładzie Bitcoina - status prawny i interpretacja ekonomiczna”, Problemy Zarządzania (Wydział Zarządzania Uniwersytetu Warszawskiego), vol. 13, no. 3(2015): 146.

12 https://coinmarketcap.com/, December 12, 2018.

13 Please see: Konrad Zacharzewski, op. cit., 1132-1140 and Konrad Zacharzewski, „Praktyczne znaczenie bitcoina na wybranych obszarach prawa prywatnego”, MoP 4(2015): 187-195.

14 (i) https://www.timesofmalta.com/articles/view/20180711/opinion/the-cradle-ofdlt-regulation-silvio-schembri.684077, October 19, 2018; (ii) https://cointelegraph. $\mathrm{com} /$ news/malta-determined-to-become-the-blockchain-island-regulations-adop- 
unofficial term now appears to be well-deserved as the Government in Valletta has introduced the regulatory framework friendly to fintech. The foregoing responds to huge interests of fintech entrepreneurs, investors and enthusiasts of new technology what has been additionally proved by the number of participants in the Malta Blockchain Summit held on from $1^{\text {st }}$ to $2^{\text {nd }}$ November $2018^{15}$.

Malta has enacted 3 comprehensive acts providing for regulatory framework to fintech, including, without limitation, the blockchain and the cryptocurrency. Chronologically, the first regulation was the Malta Digital Innovation Authority Act of (ACT XXI of 2018, CAP.591.) "MDIA" entered into the force on $15^{\text {th }}$ July $2018^{16}$. The following 2 regulations, that is the Innovative Technology Arrangements and Services Act (ACT No. XXXIII of 2018) ("ITAS") and the Virtual Financial Assets Act (ACT No. XXXIII of 2018) ("VFA") both entered into force on $1^{\text {st }}$ November $2018^{17}$.

The MDIA provides for the Malta Digital Innovation Authority (“Authority") which is designated to be the cornerstone of the Malta digital economy.

The Authority is composed of a Chairman and from four to eight remaining members constituting altogether the Board. The members of the Board shall be appointed by the Minister from persons with qualifications in, including, without limitation fintech. The members of the Board shall be appointed by the Minister for a term of one year or for such longer period as may be specified in the instrument of appointment

tion-binance-headquarters, October 19, 2018; (iii) https://www.forbes.com/sites/rachelwolfson/2018/07/31/silvio-schembri-explains-how-malta-has-become-the-worldsblockchain-island/\#36118cff2cad, October 19, 2018; (iv) https:/www.youtube.com/ watch?v=cAgTtmZOSXQ, October 19, 2018; (v) https://twitter.com/SilvioSchembri/ status/984839545760907264, October 19, 2018.

15 Eventually the number of participants amounted to 8,500 whereas initially "just" 5,000 participants declared their attendance.https:/www.forbes.com/sites/geraldfenech/2018/10/31/making-malta-the-blockchain-island-malta-blockchain-summit-kicks-off/\#57f3f64135cc; https://bitcoin.pl/dlaczego-malta-zyskala-miano-blockchain-island-podsumowanie-malta-blockchain-summit/, November 10, 2018.

16 http://www.justiceservices.gov.mt/DownloadDocument.aspx?app=lp\&itemid= 29200\&l=1, November 17, 2018.

17 http://www.justiceservices.gov.mt/DownloadDocument.aspx?app=lp\&itemid= 29277\&l=1, November 17, 2018. 
subject to a maximum of three years and the members so appointed may be re-appointed on the expiration of their term of office. The Minister is also empowered to appoint the Deputy Chairman ${ }^{18}$.

The Authority shall in particular develop all of the innovative technology arrangements and the innovative technology services in Malta, regulate and supervise the same, provide information and guidelines, advice the Minister responsible for Digital Economy ("Minister"), formulate and implement policy and strategies in connection with its functions ${ }^{19}$.

The Authority may grant an innovative technology authorisation applied for under this MDIA or under any special law which the Authority is entitled to administer and enforce, in particular, if the Authority is satisfied that:

1) the applicant is a fit and proper person to provide the innovative technology services concerned and that the applicant will comply with and observe any innovative technology authorisation rules and regulations made under the MDIA or any other special law which the Authority is entitled to administer or enforce and applicable to it;

2) the innovative technology arrangement is fit and proper and will comply with and observe any innovative technology authorisation rules and regulations made under this Act or any other special law which the Authority is entitled to administer or enforce and applicable to it.

The recognition or authorization may be issued upon voluntary application of innovative technology service providers, technical administrators, or other persons involved in innovative technology service ${ }^{20}$.

The Authority shall maintain a publicly available register of holders of the innovative technology authorizations ${ }^{21}$.

The Authority may also refuse the authorization if:

1) there are formal defects of the application;

2) the Authority has reasonable doubts as to the "quality" of the innovative technology arrangements or innovative technology service;

18 Please see: $\$ 5$ of the MDIA.

19 Please see: $\$ 6$ of the MDIA.

20 Please see: $\$ 27$.(1) of the MDIA.

21 Please see: $\$ 27 .(5)$ of the MDIA. 
3) application contained false, misleading or inaccurate information;

4) the Authority has reasonable doubts as to the capability of the applicant with regard to compliance with the applicable laws and regulations.

The Authority may also refuse the authorization if it decides that:

1) technology service or innovative technology arrangement being proposed is not compliant with the regulatory instruments in force; or

2) granting an authorisation to the applicant may pose a risk to the reputation of Malta or be otherwise not in the public interest or contrary to regulatory objectives established by the MDIA ${ }^{22}$;

As a rule the authorisation granted by the Authority cannot be assigned or transferred ${ }^{23}$, whereby the transfer to a fully controlled subsidiary of an applicant or to another legal entity that is owned and controlled by the same persons shall not be deemed to be a transfer of authorization ${ }^{24}$. The Authority shall be notified of any transactions which have the effect of the assignment or transfer of power of control ${ }^{25}$ in relation to an innovative technology services provider (in case of legal entity) unless otherwise stated in rules or guidelines issued by the Authority.

Under the provisions of the MDIA all competent authorities in Malta shall cooperate with each other if the scope of matters dealt with by given authority may affect providers of services relating to the innovative technology authorisations or affect innovative technology activities in connection with the application of the provisions of the MDIA or other specific provisions of the laws and regulations ${ }^{26}$.

The Minister may, acting on the advice on the Authority, make regulations to give effect to the MDIA, in particular, it may regulate recognition and authorization under the MDIA, including, without general conditions for granting, changing, renewing, suspending, repealing and termin-

22 Please see: $\$ 29$. let. (a) and (b) of the MDIA.

23 Please see: $\$ 33$.(1) of the MDIA.

24 Please see: $\$$ 33.(6) of the MDIA.

25 Please note that transfer of power of control means the transfer of ownership rights of $25 \%$ or more of the shares in the entity or possibility to otherwise control the same, either directly or indirectly.

26 Please see: $\$ 55 .(2)$ let. a of the MDIA. 
ating the license, as well as impose penalties for violation of the provisions of the MDIA ${ }^{27}$.

The ITAS provides for terms and conditions of recognition of the innovative technology arrangements ("ITA") and innovative technology service ("ITS") as defined in the schedules to the ITAS.

The ITA are defined as:

1) software and architectures which are used in designing and delivering DLT;

2) smart contracts and related applications, including decentralised autonomous organisations;

3) any other innovative technology arrangement which may be designated by the Minister, on the recommendation of the Authority.

The ITS are defined as:

1) review services referred to in the ITAS provided by system auditors who shall provide;

2) technical administration services referred to in the ITAS provided by technical administrators.

The Authority shall apply the provisions of the ITAS in accordance with the guidelines and to support the regulatory actions provided for in the MDIA. It is presumed that ITA and the ITS do not meet the conditions for recognition as innovative technology arrangements unless they have the functions or characteristics as set out in the schedules referred to in above ${ }^{28}$.

In case of reasonable doubt of the Authority as to functionalities or characteristics of the ITA or ITS, it may, upon a written application, issue a ruling confirming or denying the application either entirely or partially. In case of confirmation, the relevant ITA or ITS shall be considered to have the functions and, or the characteristics referred to in or be of the type or class of arrangements or services listed in the schedules and the applicant may proceed with an application for recognition under the provisions of the ITAS. In case of denying the application, the applicant shall have the right to appeal to the Tribunal under the provisions of the MDIA ${ }^{29}$.

27 Please see: $\$$ 58.(1) and $\$$ 58.(2) of the MDIA.

28 Please see: $\$ 3 .(1)$-(3) of the ITAS.

29 Please see: $\$$ 3.(4)-(5) of the ITAS. 
The applicant may apply to the Authority by making use of the relevant prescribed forms issued by the Authority for the purpose or in the absence of a prescribed form, by an application in writing providing the information required by the Authority for such purpose with reference to the subject matter of the application. The applicant shall provide the Authority with required information depending on the type of seeking recognition thereby. Following such recognition, the applicant shall be bound by the provisions of the MDIA and the ITAS ${ }^{30}$. The Authority shall maintain on website publicly available register of recognitions granted under the ITAS ${ }^{31}$.

Prior to the next point, please find this note of a terminological nature. As a result of comparison between definitions of DLT asset and the VFA, it should be noted that each VFA is a DLT asset, but not every DLT asset is the VFA ${ }^{32}$. The foregoing complies with the (slight) distinction of tokens within the cryptocurrencies as mentioned above (1. Introduction). In accordance with the said definition of the VFA and taking into account differences between the concepts of token and cryptocurrency, a cryptocurrency may be recognized to be the VFA.

The VFA provides for terms and conditions of provision of the VFA service, that is any service falling within the scope of the Second Schedule ${ }^{33}$ to the VFA, which has as its object a DLT asset being a virtual financial asset (VFA) ${ }^{34}$. The VFA service require a license to be issued by the Malta Financial Services Authority ("MFSA") ${ }^{35}$.

30 Please see: $\$$ 5.(1)-(3) of the ITAS.

31 Please see: $\$$ 6.(1)-(4) of the ITAS.

32 Please see relevant definitions as specified under $\$ 2$.(2) of the VFA.

33 Namely reception from a person of an order to buy, sell or subscribe for virtual financial assets and the transmission of that order to a third party for execution, acting as custodian or nominee holder of a virtual financial asset or operation of VFA exchange that is the exchange where only virtual financial assets may be transacted in accordance with the rules of the platform or facility, which is licensed by the MFSA under the VFA just to name a few.

34 Please see relevant definition as specified under $\$ 2$.(2) of the VFA.

35 Established under the Malta Financial Services Authority (ACT XXXIV of 1988, as amended CAP.330.). http://www.justiceservices.gov.mt/DownloadDocument.aspx?ap$\mathrm{p}=\operatorname{lom} \&$ itemid $=8804$, November 17, 2018. 
The MFSA shall conduct a test ${ }^{36}$ to determine whether or not a DLT asset is a virtual token, a virtual financial asset, a financial instrument within the meaning of the Second Schedule to the Investment Services Act (ACT XIV of 1994, as amended CAP.370.) ${ }^{37}$ or an electronic money within the meaning of the Third Schedule to Financial Institutions Act (ACT XXII of 1994, CAP.376. $)^{38}$.

If certain VFA (cryptocurrency) is deemed to be the virtual token or not to be the financial instrument or the electronic money, the issuer of such VFA is exempted from the obligation to obtain specific license under the laws and regulations.

If the issuer of the VFA is subject to the requirements as to the obtaining of the licence under the VFA, it shall appoint a VFA agent ${ }^{39}$. The role of a VFA agent is of a great importance. The VFA agent is solely entitled to apply for the licence ${ }^{40}$. Furthermore, the VFA agent shall draw up a whitepaper which complies with the requirements specified in the VFA and, in case of a DLT asset being a financial instrument or electronic money, in respective applicable laws ${ }^{41}$. The VFA agent shall also ensure that the issuer is in compliance with all applicable laws and regulations, assist him or her in complying therewith, make any and all required filings with the MFSA, discharge information obligation towards the MFSA and, in general, act as an intermediary between an issuer and the MFSA as to the matters arising out of or connected with registration of the whitepaper or the trading of the issuer's VFA on the DLT exchange ${ }^{42}$. The MFSA shall establish a public register of all registered VFA agents, which shall be accessible online

36 http://www.justiceservices.gov.mt/DownloadDocument.aspx?app=lom\&itemid= 8839, November 17, 2018.

37 Please see $\$ 47$ of the VFA.

38 http://www.justiceservices.gov.mt/DownloadDocument.aspx?app=lom\&itemid= 8843, November 17, 2018.

39 Pursuant to relevant definition as specified under $\$ 2$.(2) of the VFA, it means a person registered with the competent authority under the VFA and authorised to carry out profession of (i) advocate, accountant or auditor, (ii) a firm of advocates, accountants, or corporate service providers, or (iii) a legal organization which is wholly owned and controlled by persons referred as referred to in above.

$40 \$ 14$.(1) of the VFA.

41 Please see: $\$ 3$.(1) let. a and let. $\mathrm{b}$ in connection with $\$ 4$ of the VFA.

42 Please see: $\$ 7 .(1)$ and $\$ 7 .(2)$ of the VFA. 
updated on a regular basis ${ }^{43}$. Additionally, such issuer shall have a website that is in compliance with rules to be set by the MFSA ${ }^{44}$ and advertise the offering in compliance with the provision of the $\mathrm{VFA}^{45}$.

To sum up, the applicant shall satisfy the following requirements ${ }^{46}$ :

1) appoint the VFA agent;

2) be a fit and proper to provide VFA service ${ }^{47}$;

3) comply with the laws and regulations;

4) be a resident or be incorporated in Malta;

5) appoint officers.

The VFA also provides for right to appeal to the Tribunal ${ }^{48}$ from any decision, notice, administrative penalty or refusal, variation, cancellation and suspension of license.

Although, the scope of regulatory works made by Malta shall be appreciated, I find a little bit of a downside of the legislative technique. The division of statutory matters between the MDIA and the ITAS seems to be an unsatisfactory solution, because in essence, both acts constitute unity through their mutual cross-references and a common conceptual grid. Perhaps the legislator objective was that the MDIA shall regulate authorities whereas the ITAS shall regulate the procedure before these authorities, however I do not find sufficient arguments for such division. The ITAS contains also many provisions addressed to the Authority, which also supports the idea of "merging" the above-mentioned acts.

It appears that Malta may be now deservedly called as the "Blockchain Island". However, for now it is too early to comment on how the enacted laws and regulations work in practice, because the same came into force recently. The adopted legal solutions constitute a framework to be filled in by implementing acts and practice of the authorities. It seems that quite broad prerogatives of the executive bodies will allow achieving the goal of ensuring a stable and friendly legal environment. Eventually, the assess-

43 Please see: $\$ 7 .(3)$ of the VFA.

44 Please see: $\$ 5$.(1) of the VFA.

45 Please see: $\$$ 6.(1) of the VFA.

46 Please see: $\$ 14$ of the VFA.

47 I n case of an entity, it applies to its beneficial owners, officer of corporate bodies thereof.

48 Established under the provisions of the MFSA. 
ment of effectiveness and suitability of the adopted laws and regulations will depend on the actions taken in practice by the competent authorities and the numbers of entities running business operation.

\section{REGULATION OF CRYPTOCURRENCY IN ESTONIA}

In the course of implementation of the Directive (EU) 2015/849 of the European Parliament and of the Council on the prevention of the use of the financial system for the purposes of money laundering or terrorist financing, amending Regulation (EU) No 648/2012 of the European Parliament and of the Council, and repealing Directive 2005/60/EC of the European Parliament and of the Council and Commission Directive 2006/70/EC (Official Journal of the European Union L 214/29) ("IV AML Directive") ${ }^{49}$ Estonia has amended the act on Money Laundering and Terrorist Financing Prevention Act (RT I, 17.11.2017, 2) ${ }^{50}$ ("MLTFPA") accordingly and included also proposal of the European Commission for the amendment to IV AML Directive ${ }^{51}$ aimed at subjecting custodian wallet providers and virtual currency exchange platforms to scope of the IV AML Directive ${ }^{52}$. The government in Tallinn has gone even one step further because it has decided not only to introduce legal definitions of "virtual currency" and "virtual currency wallet service" but also to regulate conducting business in the field of exchanging virtual currency and virtual currency wallet as the first country within the European Union. The MLTFPA entered into force on $27^{\text {th }}$ November 2017.

49 Please note that IV AML Directive has been amended by the Directive (EU) 2018/843 of the European Parliament and of the Council of 30 May 2018 amending Directive (EU) 2015/849 on the prevention of the use of the financial system for the purposes of money laundering or terrorist financing, and amending Directives 2009/138/EC and 2013/36/EU (Text with EEA relevance) ("V AML Directive") which introduced, among other things, definitions of "virtual currencies" and "custodian wallet provider".

50 https://www.riigiteataja.ee/en/eli/521122017004/consolide (in English), November $17,2018$.

51 Please see: annotation no. 1.

52 https://eur-lex.europa.eu/legal-content/EN/TXT/PDF/?uri=CELEX:52016PC0450\&from=EN, December 16, 2018. 
The MLTFPA applies to providers of a service of exchanging a virtual currency against a fiat currency and providers of a virtual currency wallet service ${ }^{53}$. The term "virtual currency" under the MLTFPA means a value represented in the digital form, which is digitally transferable, preservable or tradable and which natural persons or legal persons accept as a payment instrument, but that is not the legal tender of any country or funds for the purposes of Article 4(25) of Directive (EU) 2015/2366 of the European Parliament and of the Council on payment services in the internal market, amending Directives 2002/65/EC, 2009/110/EC and 2013/36/EU and Regulation (EU) No 1093/2010, and repealing Directive 2007/64/EC (Official Journal of the European Union 337/35) or a payment transaction for the purposes of points (k) and (l) of Article 3 of the same Directive, whereas the term "virtual currency wallet service" under the MLTFPA means a service in the framework of which keys are generated for customers or customers' encrypted keys are kept, which can be used for the purpose of keeping, storing and transferring virtual currencies $^{54}$.

The regulatory powers and duties related to cryptocurrency market in Estonia are vested in the Financial Intelligence Unit (rahapesu andmebüroo) ("FIU"). The FIU is an independent structural unit of the Police and Border Guard Board and performs its duties arising from the MLTFPA independently and makes decisions concerning the actions provided for therein ${ }^{55}$. The scope of duties of the FIU includes:

1) gathering, registration, processing and analysis of information referring to money laundering and terrorist financing;

2) strategic analyse that covers the risks, threats, trends and ways of operation of money laundering and terrorist financing;

3) tracing criminal proceeds and application of the enforcement powers of the state on the grounds and within the scope provided by law;

4) supervision over the activities of obliged entities in complying with the MLTFPA, unless otherwise provided by law;

53 Please see: $\$ 2 .(1) 10)$ and $\$ 2$.(1)(11 of the MLTFPA.

54 Please see: $\$ 3.9$ ) and $\$ 3.10$ ) of the MLTFPA.

55 Please see: $\$ 53.1$ ) of the MLTFPA. 
5) informing the public about the prevention and identification of money laundering and terrorist financing, and preparing and publishing an aggregate overview at least once a year;

6) $\mathrm{AML} / \mathrm{CFT}^{56}$ cooperation with obliged entities, competent supervisory authorities and investigative bodies;

7) training obliged entities' staff, investigative bodies, prosecutors and judges in AML/CFT matters;

8) organisation of international communication and exchange of information in accordance with $\$ 63$ of the MLTFPA;

9) performance of duties arising from the International Sanctions Act (RT I 2010, 26, 129) ("ISA") ${ }^{57}$;

10) conducting misdemeanour proceedings provided for in the MLTFPA;

11) processing applications for authorisations, suspending or prohibiting business activities or suspending or revoking an authorisation in accordance with the procedure set out in the General Part of the Economic Activities Code Act (RT I, 25.03.2011, 1) ${ }^{58}$ ("GPEACA"), including differences arising out of the MLTFPA.

The FIU is also empowered to issue precepts ${ }^{59}$, including power to suspend a transaction or impose restrictions on the disposal of property on an account, property kept on an account or property constituting the object of the transaction, professional act or professional service or other property suspected of being associated with money laundering or terrorist financing for up to 30 calendar days as of the delivery of the precept ${ }^{60}$ as well as guidelines aimed at providing assistance to entities to comply with the MLTFPA ${ }^{61}$.

56 Anti-money laundering and countering the financing of terrorism.

57 https://www.riigiteataja.ee/en/eli/503072014002/consolide (in English), December 20, 2018.

58 https://www.riigiteataja.ee/en/eli/530102013062/consolide (in English), December 20, 2018.

$59 \$ 55.1)$ of the MLTFPA.

60 Please see: $\$ 57.1$ ) of the MLTFPA.

61 Please see: $\$ 56$ of the MLTFPA. As of 30.12 .2018 the FIU has issued 2 guidelines, i.e. Advisory guidelines of the Financial Intelligence Unit regarding the characteristics of transactions with a money laundering suspicion https://www2.politsei.ee/dotAsset/39481. pdf, December 20, 2018 and Advisory guidelines of the Financial Intelligence Unit re- 
The provisions of the MLTFPA ${ }^{62}$ provide for two types of authorization (licenses) to be issued by FIU which allow for legal business operation in the field of:

1) provision of a service of exchanging a virtual currency against a fiat currency; and

2) provision of a virtual currency wallet service.

Licence for provision of a service of exchanging a virtual currency (cryptocurrency) against a fiat currency enables the applicant to run trading platform (so-called cryptocurrency exchange) that allows to exchange of cryptocurrencies to fiat currencies and vice versa.

Licence for provision of a virtual currency (cryptocurrency) wallet service enables the applicant to run platform (so-called cryptocurrency wallet) that allows to keep, store and transfer cryptocurrencies.

The MLTFPA provides for fast-track of obtaining of a licence. In accordance with the MLTFPA, the FIU shall grant or refuse to grant authorisation not later than within 30 working days following the date of submission of the application ${ }^{63}$.

In order to obtain the licence, an applicant ${ }^{64}$ shall fill the FIU with an application, including set internal control rules and internal procedure rules up in accordance $\$ \$ 14$ and 15 of the MLTFPA, that is in particular known-your-customer (KYC) and anti-money laundering (AML) procedures and duties arising out of the ISA. Furthermore, the applicant shall appoint a person who acts as a contact person of the FIU (compliance officer $^{65}$. In accordance with the MLTFPA only a person who has the education, professional suitability, the abilities, personal qualities, experience and impeccable reputation required for performance of the duties of a compliance officer may be appointed as a compliance officer. The appointment of a compliance officer is coordinated with the FIU ${ }^{66}$. Although,

garding the characteristics of transactions suspected of terrorist financing https://www2. politsei.ee/dotAsset/39479.pdf, December 20, 2018.

62 Please see: $\$ 70 .(1) 4)$ and $\$ 70 .(1) 5)$ of the MLTFPA.

63 Please see: $\$ 71$ of the MLTFPA.

64 Please note that an applicant may be only a company or a branch thereof registered in Estonian commercial register.

65 Please see: $\$ 17 .(2)$ of the MLTFPA.

66 Please see: $\$ 17 .(5)$ of the MLTFPA. 
the set of documents to be provided in order to obtain the licence is not extensive, in some cases there is a need to provide the FIU with additional information. If the applicant, a member of its management body, procurator, beneficial owner or owner is a foreign national or where the applicant is a foreign service provider, a certificate of the criminal records database or an equal document issued by a competent judicial or administrative body of its country of origin, which certifies the absence of a penalty for an offence against the authority of the state or a money laundering offence or another wilfully committed criminal offence and has been issued no more than 3 months ago and has been authenticated by a notary or certified in accordance with an equivalent procedure and legalised or certified with a certificate replacing legalisation (apostille), unless otherwise provided by an international agreement ${ }^{67}$.

The licence ${ }^{68}$ will be granted to an applicant where:

1) the applicant, a member of its management body, procurator, beneficial owner and owner does not have any unexpired penalty for a criminal offence against the authority of the state, criminal offence relating to money laundering or another wilfully committed criminal offence;

2) the compliance officer appointed by the undertaking on the basis of $\$ 17$ of the MLTFPA meets the requirements provided for in this Act;

3) the applicant's subsidiary for whose activities the authorisation to be applied in the name of the applicant is to be used meets the requirements specified in clauses 1 and 2 of referred to herein above.

The FIU shall revoke the authorization ${ }^{69}$ in case of:

1) intentional submission of incorrect information by the applicant, provided that if such information had not been submitted, the grant of an activity licence would have been denied;

2) renouncement of economic activities by the applicant;

67 Please see: $\$ 70.3)(8)$ of the MLTFPA.

68 Please note that the applicant may hold both licenses as referred to in above, however it shall fill the FIU with 2 separate applications.

69 Please see: $\$ 75$ of the MLTFPA in connection with $\$ 37.1$ ) of the GPEACA, December 15, 2018. 
3) validity of a relevant prohibition on economic activities imposed by a court judgment or arising from law in a relevant area of activity in respect of the applicant;

4) the Financial Supervision Authority has granted authorisation to the applicant;

5) the applicant repeatedly fails to follow the precepts of the supervisory authority;

6) the applicant has not commenced operation within 6 months from the issue of the authorisation.

According to the Register of Economic Activities in Estonia (Majandustegevuse register) the FIU has issued 597 licenses for provision of service of exchanging a virtual currency (cryptocurrency) against a fiat currency ${ }^{70}$ and 514 licenses for provision of a virtual currency (cryptocurrency) wallet service as of $29.12 .2018^{71}$.

The number of licenses granted over the course of slightly more than one year since amendment to the MLTFPA has proven that the decision of government in Tallinn to implement friendly legal framework with respect to cryptocurrency business responds to the huge interests of fintech entrepreneurs and the needs of investors.

\section{REGULATION OF CRYPTOCURRENCY IN SWITZERLAND}

Although Switzerland has not enacted any specific regulations on the fintech, including, without limitation, cryptocurrencies, it has recognized importance of the fintech ${ }^{72}$ as well as identified certain barriers of the regulatory framework thereto ${ }^{73}$ and is still working on reducing such barriers ${ }^{74}$.

70 To compare, the number of licenses granted for provision of traditional - fiat currency exchange amounts to 49 .

71 https://mtr.mkm.ee/taotluse_tulemus (in English), December 15, 2018.

72 https://www.efd.admin.ch/efd/en/home/dokumentation/nsb-news_list.msg-id-70 165.html, December 15, 2018.

73 https://www.newsd.admin.ch/newsd/message/attachments/45938.pdf, December 20, 2018.

74 According to the Swiss Minister of Finance, Ueli Maurer, Switzerland is to introduce amendments to the existing laws and regulations, including the civil code and the 
The Swiss Financial Market Supervisory Authority ("FINMA") differentiates, based on economic function, 3 types of the following cryptocurrencies:

1) payment tokens that are intended to be used, now or in the future, as a means of payment for acquiring goods or services or as a means of money or value transfer;

2) utility tokens that are intended to provide access digitally to an application or service by means of a blockchain-based infrastructure; and

3) asset tokens that represent assets such as a debt or equity claim on the issuer, analogous to equities, bonds or derivatives ${ }^{75}$.

The foregoing distinction in particular translates into application of laws and regulation of the capital market, including, without limitation, provisions of the act on Financial Market Infrastructures and Market Conduct in Securities and Derivatives Trading of 19 June 2015 (958.1, as amended) ("FMIA") ${ }^{76}$ to tokens. The FINMA shall determine as to whether tokens referred to in above qualify as securities in the meaning of the FMIA $^{77}$. In general, the FMIA considers only the asset tokens as securities and utility tokens provided that they have an investment purpose at the point of their issue $^{78}$. Thus, the payment tokens are not subject to the FMIA.

The cryptocurrency phenomenon shall be subject to the act on the Anti-Money Laundering and Terrorist Financing in the Financing Sector of 10 October 1997 (955.0, as amended) ("AMLA"). The applicability of the AMLA was confirmed by FINMA as it declared that to thee issuing of pay-

bankruptcy law, instead of enactment of any new laws; https://cointelegraph.com/news/ swiss-finance-minister-rejects-specific-blockchain-legislation-in-favor-of-current-laws December 15, 2018.

75 Guidelines for enquiries regarding the regulatory framework for initial coin offerings (ICOs) of 16th February 2018 https://www.finma.ch/en/news/2018/02/20180216mm-ico-wegleitung/ December 20, 2018.

76 https://www.admin.ch/opc/en/classified-compilation/20141779/index.html (unofficial translation in English), December 15, 2018.

77 Pursuant to Art. 2 let. B of the FMIA securities are standardised certificated or uncertificated securities, derivatives and intermediated securities which are suitable for mass standardised trading.

78 Guidelines for enquiries regarding the regulatory framework for initial coin offerings (ICOs) of 16th February 2018 https://www.finma.ch/en/news/2018/02/20180216mm-ico-wegleitung/, December 20, 2018. 
ment tokens constitutes the issuing of a means of payment subject to this regulation as long as tokens can be transferred technically on a blockchain infrastructure, whereas in case of utility tokens, AMLA is not applicable as long as the main reason for issuing the tokens is to provide access rights to a non-financial application of blockchain technology ${ }^{79}$. The AMLA provides for legal definition of the financial intermediary, that is a person who on a professional basis accept or hold on deposit assets belonging to others or who assist in the investment or transfer of such assets, including in particular person who provides services related to payment transactions, in particular by carrying out electronic transfers on behalf of other persons, or who issues or manages means of payment such as credit cards and travellers' cheques ${ }^{80}$. Consequently, exchanging cryptocurrency for fiat money or a different cryptocurrency and provision of custody wallet services shall be subject to the provisions of the AMLA referred to in above.

The cryptocurrency phenomenon shall be also subject to Ordinance on Banks and Savings Banks of (952.02, as amended) (“OBSB”) ${ }^{81}$. Provided that issuing of tokens is associated with liabilities of debt capital character (e.g. promises to return capital with a guaranteed return), the funds raised shall be treated as deposits and, therefore a banking licence shall be required for provision of such services ${ }^{82}$. However, providers that accept public funds up to a total value of CHF 1 million are exempted from the requirement to have a banking license, provided that they notify of their customers in writing that they are not subject to supervision by the FINMA and that the deposits are not protected by deposit insurance ${ }^{83}$.

79 Guidelines for enquiries regarding the regulatory framework for initial coin offerings (ICOs) of 16th February 2018 https://www.finma.ch/en/news/2018/02/20180216mm-ico-wegleitung/, December 20, 2018.

80 Please see: https://www.admin.ch/opc/en/classified-compilation/19970427/index. html\#fn-\#a2-14 (unoffcial translation in English), December 20, 2018.

81 https://assets.kpmg/content/dam/kpmg/ch/pdf/ordinance-on-banks-and-savingsbanks-en.pdf (unofficial translation in English), December 20, 2018.

82 Guidelines for enquiries regarding the regulatory framework for initial coin offerings (ICOs) of 16th February 2018 https://www.finma.ch/en/news/2018/02/20180216mm-ico-wegleitung/, December 20, 2018.

83 https://www.admin.ch/gov/en/start/documentation/media-releases.msg-id-67436 .html, December 20, 2018. 
At the level of cantonal administration, one cannot miss the Canton of Zug. The Commercial Register Office in the Canton of Zug not only accepts certain cryptocurrencies as payment for administrative costs but accepts cryptocurrencies as an in kind-contribution for incorporation of a company ${ }^{84}$. At the same time the city of Zug accepts fees for municipal services up to CHF 200 paid with bitcoin ${ }^{85}$. The city of Zug is also home to Crypto Valley Association - an independent, government-supported association established to take full advantage of Switzerland's strengths to build the world's leading blockchain and cryptographic technologies ecosystem $^{86}$. The Canton of Zug has been recently distinguished as the fastest-growing tech community in Europe ${ }^{87}$.

The municipality of Chiasso located in the Canton of Ticino, followed the steps of the city of Zug as it commenced accepting fees for tax payment with bitcoin up to CHF $250^{88}$.

\section{CONCLUSIONS}

The current level of regulations regarding fintech, including, without limitation cryptocurrencies, presented herein illustrates diverse approach to that phenomena. On one hand, certain states, do not introduce any new laws and regulations, however they do adopt the current ones in order to mitigate barriers. The prominent exponent of such approach is Switzerland. On the other hand, certain states introduce either partial regulations, which may be exemplified by Estonia, or comprehensive regulations as in the case of Malta, which is still an unusual approach. I would like to

${ }^{84}$ https://www.zg.ch/behoerden/volkswirtschaftsdirektion/handelsregisteramt/aktuell/handelsregisteramt-zug-akzeptiert-kryptowaehrungen-bitcoin-und-ether-als-zahlungsmittel, December 20, 2018.

85 http://www.stadtzug.ch/de/ueberzug/ueberzugrubrik/aktuelles/aktuelles informationen/welcome.php?action=showinfo\&info_id=351680\&ls=0\&sq=\&kategorie_id=\&date_from=\&date_to, December 15, 2018.

86 https://cryptovalley.swiss/about-the-association/, December 15, 2018.

87 https://cointelegraph.com/news/switzerlands-crypto-valley-zug-ranked-fastestgrowing-tech-hub-in-europe, December 23, 2018.

88 https:/www.chiasso.ch/possibilita-pagamento-imposte-bitcoin/, December 20, 2018. 
express an opinion that the tendency of states will change towards at the least partial regulation of blockchain and cryptocurrency phenomenon.

\section{REFERENCES}

Sobiecki, Grzegorz. 2015. Regulowanie kryptowalut w Polsce i na świecie na przykładzie Bitcoina - status prawny i interpretacja ekonomiczna, Problemy Zarządzania (Wydział Zarządzania Uniwersytetu Warszawskiego), vol. 13, nr 3(54), t. 1: 146.

Szostek, Dariusz. 2018. Blockchain a prawo, 129. Warsaw: C.H. Beck.

Szymankiewicz, Marcin. 2014. Bitcoin wirtualna waluta Internetu, 102. Gliwice: Onepress.

Zacharzewski, Konrad. 2014. „Bitcoin jako przedmiot stosunków prawa prywatnego", MoP 21: 1136.

Zacharzewski, Konrad. 2015. „Praktyczne znaczenie bitcoina na wybranych obszarach prawa prywatnego”, MoP 4: 187-195. 